\title{
A Case of Chylothorax with Interesting Etiology
}

\author{
Etyolojisi İlginç bir Şilotoraks Olgusu
}

Nalan Ogan', Evrim Eylem Akpınar', Tevfik Kaplan², Gökçe Türker³, Meral Gülhan'

\begin{abstract}
Chylothorax occurs when chylous fluid from the lymphatic system accumulates in the pleural space due to damage to the ductus thoracicus. The milky fluid contains a high concentration of triglycerides in the form of chylomicrons. The initial test for diagnosis is analysis of the pleural fluid. It may be associated with a number of traumatic and nontraumatic conditions. Chylothorax was diagnosed in a patient who underwent an operation for a thoracic vertebra fracture 4 years earlier who presented with bronchitis. Fixation pins in the lower thoracic vertebra inserted in the operation were observed on thorax computerized tomography. No other etiological cause for chylothorax was found based on the patient history, physical examination, or advanced examinations. It was decided that the collapse and fracture operation had a late complication. This case is presented as an interesting etiological cause of chylothorax as, to our knowledge, there is no similar case in the literature.
\end{abstract}

Key words: Chylothorax, vertebra operation, cough.

\section{Özet}

Şilotoraks, duktus torasikusun zarar görmesine bağlı şilöz sıvının lenfatik sistemden plevral boşluğa geçmesidir ve süt rengi sıvıda şilomikron formunda yüksek konsantrasyonda trigliserid içerir. Tanı için başlangıç testi plevra sıvı analizidir. Travmatik ve nontravmatik birçok nedene bağlı olabilir. Bir ay önceki geçirdiği bronşit neden ile öksürük şikâyeti olan ve şilotoraks saptanan olguda, dört yil önce torakal vertebra kırığı nedeni ile ameliyat öyküsü de mevcuttu. Toraks bilgisayarlı tomografide, alt torakal vertebrada, operasyonda yerleştirilen fiksasyon çivisinin anteriora doğru kaydığı tespit edildi. Öykü, fizik muayene ve ileri tetkiklerle şilotoraksa neden olan diğer etiyolojik neden bulunamadı ve çökme kırı̆ı̆ ameliyatının geç komplikasyonu olduğuna karar verildi. Daha önce literatürde bu ilginç etiyolojik neden ile bildirilen benzer bir olgu bulunmaması nedeni ile sunulmuştur.

Anahtar Sözcükler: Şilotoraks, vertebra operasyonu, öksürük.
Chylothorax, an accumulation of lymphatic fluid in the pleural space, is a rare condition associated with a high risk of morbidity and mortality. Patients with this condition develop a severe loss of essential proteins, immunoglobulins, lipids, vitamins, and electrolytes due to the leakage of chyle. The presence of a chylomicrons and a triglyceride level above $110 \mathrm{mg} / \mathrm{dL}$ is diagnostic of chylothorax (1). While a therapeutic thoracentesis provides relief from symptoms, appropriate therapeutic procedures should be instituted to stop the leakage of chyle into the pleural space due to persistent

'Department of Chest Diseases, Ufuk University Faculty of Medicine, Ankara, Turkey

${ }^{2}$ Department of Thoracic Surgery, Ufuk University Faculty of Medicine, Ankara, Turkey

${ }^{3}$ Departmant of Infectious Diseases, Kirıkkale University Faculty of Medicine, Kırıkkale, Turkey

'Ufuk Üniversitesi Tıp Fakültesi, Göğüs Hastalıkları Anabilim Dalı, Ankara

${ }^{2}$ Ufuk Üniversitesi Tıp Fakültesi, Göğüs Cerrahisi Anabilim Dalı, Ankara

${ }^{3}$ Kırıkkale Üniversitesi Tıp Fakültesi, Enfeksiyon Hastalıkları Ana Bilim Dalı, Kırıkkale

Submitted (Başvuru tarihi): 14.04.2017 Accepted (Kabul tarihi): 15.09.2017

Correspondence (iletişim): Nalan Ogan, Department of Chest Diseases, Ufuk University Faculty of Medicine, Ankara, Turkey

e-mail: nalanogan@gmail.com 
nutritional deterioration (2). It often requires an individual management approach based on the etiology. Multiple etiologies, arising from acquired, benign, or malignant causes, are possible. Presently described is a unique case of chylothorax associated with a rare etiology.

\section{CASE}

A 75-year-old female patient had received non-specific antibiotic treatment twice at an external center for a complaint of cough and purulent sputum ongoing for approximately 1 month. She then presented to our outpatient clinic due to the persistent cough. She was admitted to evaluate the fluid etiology, since a chest $X$-ray showed pleural effusion (Figure 1). She had a history of chronic myeloid leukemia (CML) for 3 years and a diagnosis of hypertension (HT) for 40 years. She underwent surgery for a vertebral compression fracture caused by osteoporosis 4 years previously. She was taking an oral tyrosine kinase inhibitor for the CML, and a calcium channel blocker for the HT. A physical examination revealed dullness below the scapula area in the right hemithorax with no respiratory sound. Other system signs were normal. Routine laboratory test results were normal with the exception of the C-reactive protein level (32.7 mg/L) and sedimentation rate $(55 \mathrm{~mm} / \mathrm{hour})$. A peripheral smear and whole blood count were normal. The CML was in remission. An opaque white fluid of a slightly pink hue was withdrawn through thoracentesis. The biochemical analysis indicated that the fluid was an exudate with a triglyceride level of $447 \mathrm{mg} / \mathrm{dL}$. The diagnosis of chylothorax was confirmed. The patient had no history of surgical intervention associated with a trauma or iatrogenic chylothorax. She underwent a thoracic CT scan to evaluate the etiology of chylothorax. The CT showed a massive pleural effusion in the right hemithorax, and less pleural effusion in the left hemithorax, as well as atelectasis of the right lower lobe of the lung associated with effusion, cardiomegaly, and evidence of a compression fracture at T12 and fixation pins at T10-T11. It also revealed that the fixation pins placed in the thoracic vertebrae 10 and 11 due to a compression fracture 4 years earlier had migrated from the anterior vertebral corpus to the prevertebral space (Figure 2). Oral treatment was discontinued and replaced with appropriate total parenteral nutrition. Following consultation with the thoracic surgery department, the patient underwent a tube thoracotomy followed by pleurodesis with talc. After the pleurodesis procedure, a chest $X$-ray confirmed successful treatment (Figure 3).

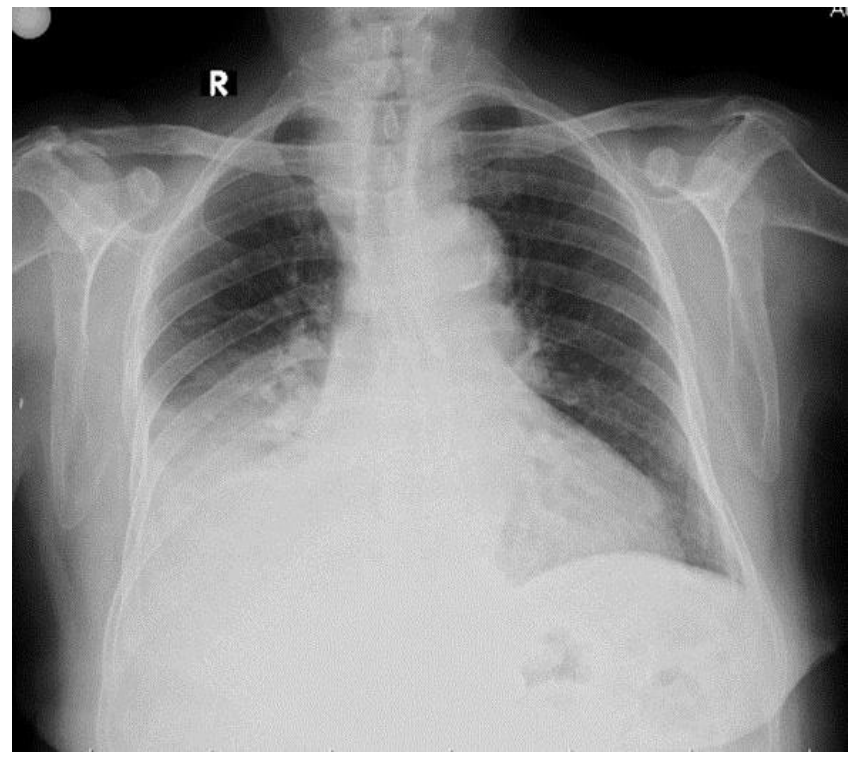

Figure 1: Initial posterioanterior chest $X$-ray, pleural effusion at right hemithorax

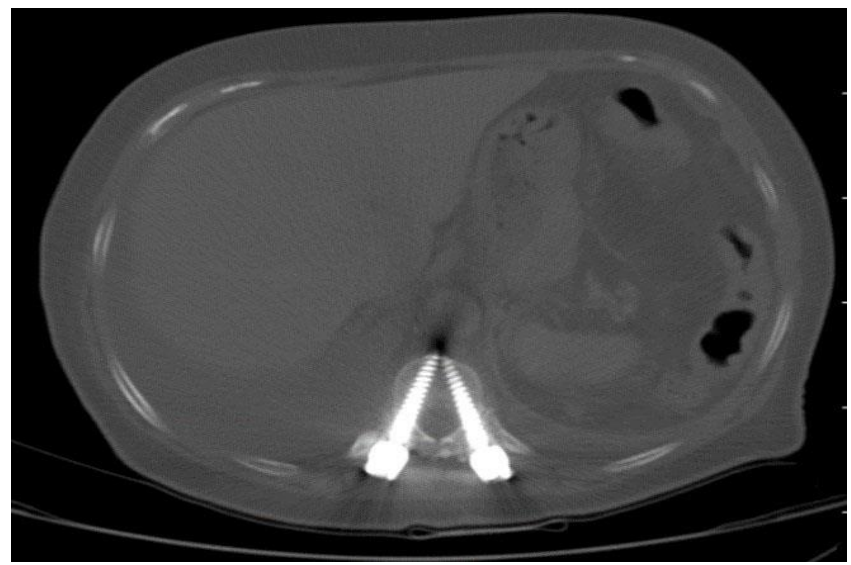

Figure 2: The tip of the fixation nails extend from the anterior vertebra corpus to the prevertebral area

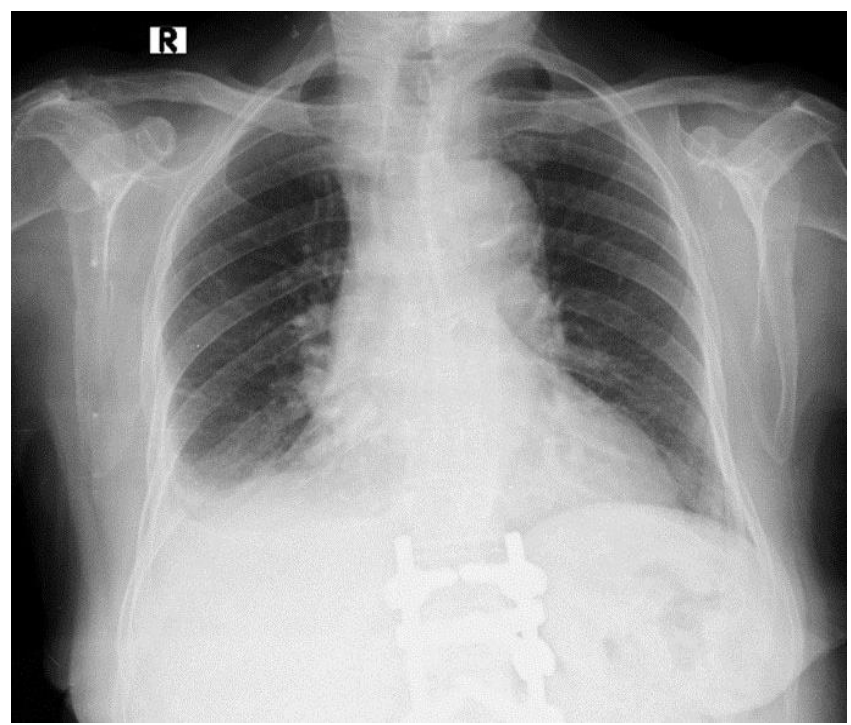

Figure 3: Control chest X-ray after pleurodesis. 


\section{DISCUSSION}

Although chylothorax is most commonly associated with trauma, it has multiple etiologies (3). Our patient had no prior trauma; history of neck, thoracic, or abdominal surgery; or known causes of iatrogenic chylothorax (lumbar arteriography, subclavian vein catheterization) (2). She also had no nontraumatic etiology, including malignancy, sarcoidosis, retrosternal goiter, amyloidosis, vena cava superior thrombosis, benign tumors, or other rare causes (4). Chylothorax was considered to be associated with the trauma effect of the fixation pins placed into the thoracic vertebrae that migrated to the prevertebral space at the course of the ductus thoracicus. A literature review determined that patients who undergo vertebral surgery may experience minor leakage of chyle arising from intraoperative trauma (5). A review of 11 cases evaluated patients who underwent surgery for fusion or decompression. All of these patients were treated by anterior approach, whereas our patient had posterior approach surgery. In this series, all of the patients had early complications. A laceration of the ductus thoracicus was noted and repaired intraoperatively in 3 patients, preventing any postoperative leakage (6). Other patients underwent postoperative drainage, and only 1 patient required surgical ductus ligation. There are 3 cases in the literature in which a posterior approach to the vertebral column was used and acute chylothorax developed. In this case, the complication developed 4 years after the surgery, possibly not due to intraoperative damage, but as a result of chronic irritation of the inserted instrument (7-9).

We attributed development of chylothorax 4 years after surgery to the migration of fixation pins due to changes in vertebral structure. In this report of late chylothorax there was an additional complaint of a prolonged severe cough associated with bronchial infection.

\section{CONCLUSION}

No surgical intervention was required for our patient whose chylothorax was controlled with pleurodesis. She was monitored for any possible recurrence. We believe that utmost care should be exercised during the follow-up of the increasing number of patients undergoing vertebral fixation operations in orthopedics clinics.

\section{CONFLICTS OF INTEREST}

None declared.

\section{AUTHOR CONTRIBUTIONS}

Concept - E.E.A., N.O., T.K., G.T., M.G.; Planning and Design - T.K., N.O., E.E.A., G.T., M.G. Supervision M.G., N.O., T.K., G.T., E.E.A. Funding - M.G.; Materials - T.K.; Data Collection and/or Processing - N.O., G.T.; Analysis and/or Interpretation - N.O.; Literature Review N.O., T.K.; Writing - N.O.; Critical Review - M.G.

\section{YAZAR KATKILARI}

Fikir - E.E.A., N.O., T.K., G.T., M.G.; Tasarım ve Dizayn - T.K., N.O., E.E.A., G.T., M.G.; Denetleme - M.G., N.O., T.K., G.T., E.E.A.; Kaynaklar - M.G.; Malzemeler T.K.; Veri Toplama ve/veya İşleme - N.O., G.T.; Analiz ve/veya Yorum - N.O.; Literatür Taraması - N.O., T.K.; Yazıyı Yazan - N.O.; Eleştirel İnceleme - M.G.

\section{REFERENCES}

1. Staats BA, Ellefson RD, Budahn LL, Dines DE, Prakash UB, Offord K. The lipoprotein profile of chylous and nonchylous pleural effusions. Mayo Clin Proc 1980; 55):700-4.

2. McGrath EE, Blades Z, Anderson PB. Chylothorax: aetiology, diagnosis and therapeutic options. Respiratory Medicine 2010; 104:1-8. [CrossRef]

3. Doerr CH, Miller DL, Ryu JH. Chylothorax. Semin Respir Crit Care Med 2001; 22:617-26. [CrossRef]

4. Nadolski G. Nontraumatic chylothorax: diagnostic algorithm and treatment options. Tech Vasc Interv Radiol 2016; 19:286-90. [CrossRef]

5. Klezl Z, Swamy GN, Vyskocil T, Kryl J, Stulik J. Incidence of vascular complications arising from anterior spinal surgery in the thoraco-lumbar spine. Asian Spine J 2014; 8:59-63. [CrossRef]

6. Su IC, Chen CM. Spontaneous healing of retroperitoneal chylous leakage following anterior lumbar spinal surgery: a case report and literature review. Eur Spine J 2007; 16:332-7. [CrossRef]

7. Rames RD, Schoenecker PL, Bridwell KH. Chylothorax after posterior spinal instrumentation and fusion. Clin Orthop Relat Res 1990; 261:229-32. [CrossRef]

8. Weening AA, Schurink B, Ruurda JP, van Hillegersberg R, Bleys RLAW, Kruyt MC. Chyluria and chylothorax after posterior selective fusion for adolescent idiopathic scoliosis. Eur Spine J 2018 [In press] [CrossRef]

9. Ameri E, Ghandhari H, Nabizadeh N, Hesarikia H. Chylothorax complication in posterior spinal fusion (report of one case). IJOS 2014; 12:80-3. 